FIN AL REPORT

U.S. Department of Energy

\title{
A BROAD SPECTRUM CATALYTIC SYSTEM FOR REMOVAL OF TOXIC ORG ANICS FROM WATER BY DEEP OXIDATION
}

\author{
Ayusman Sen \\ Department of Chemistry \\ The Pennsylvania State University \\ University Park, PA 16802 \\ Phone: (814) 863-2460; FAX: (814) 863-8403 \\ E-mail: asen@chem.psu.edu
}

Project N umber: 54122

Grant Number: DE-FG07-96ER14694

Project Duration: 9/ 15/ 96- 9/ 14/ 99

$\widehat{\gamma}$ 


\section{TABLE OF CONTENTS}

page

Executive Summary

Research 0 bjectives

Methods and Results

Relevance, Impact and Technology Transfer

Project Productivity

Personnel Supported

Publications in Peer-Reviewed Journals

Interactions

Literature Cited
3

4

6

28

31 


\section{EXECUTIVE SUMMARY}

A most pressing need for the DOE environmental management program is the removal of toxic organic compounds present in groundwater and soil at specific DOE sites. While several remediation procedures have been proposed, they suffer from one or more draw backs. The objective of the present research was to develop new catalytic procedures for the removal of toxic organic compounds from the environment through their deep oxidation to harmless products.

In water, metallic palladium was found to catalyze the deep oxidation of a wide variety of toxic organic compounds by dioxygen at $80-90^{\circ} \mathrm{C}$ in the presence of carbon monoxide or dihydrogen. Several classes of organic compounds were examined: benzene, phenol and substituted phenols, nitro and halo organics, organophosphorus, and organosulfur compounds. In every case, deep oxidation to carbon monoxide, carbon dioxide, and water occurred in high yields, resulting in up to several hundred turnovers over a $24 \mathrm{~h}$ period. For substrates susceptible to hydrogenation, the conversions were generally higher with dihydrogen than with carbon monoxide.

It is clear from the results obtained that we have discovered an exceptionally versatile catalytic system for the deep oxidation of toxic organic compounds in water. This system possesses several attractive features not found simultaneously in other reported systems. These are (a) the ability to directly

utilizedioxygen as the oxidant, (b) the ability to carry out the deep oxidation of a particularly wide range of functional organics, and (c) the ease of recovery of the catalyst by simplefiltration. 


\section{RESEARCH OBJECTIVES}

Toxic organics in water constitute an important environmental hazard. ${ }^{1} \mathrm{M}$ any are byproducts of industrial production. Several are introduced into aqueous systems through their usage, e. g., as biocides. Chlorinated organics are an important class of toxic pollutants that have become widely dispersed in the environment due to their use as solvents, degreasing agents, and in cleaning and fabrication applications. For example, chloroorganics, such as tri and tetrachloroethylene, are the principal constituents of DNAPL (denser than water non-aqueous phase liquids) that are present in $60 \%$ of the DOE "superfund" sites. Any procedure for the removal of toxic organics from water must meet the following criteria. First, the process must be economical, i. e., only inexpensive reagents and catalysts may be used. Second, the procedure should be applicable to a broad spectrum of toxic organics with a variety of functional groups. Finally, the procedure should not result in the introduction of anything to the water that needs to be removed subsequently, i. e., simultaneous water purification and contaminant destruction should be feasible.

One obvious solution to the problem is bioremediation. ${ }^{2}$ However, many of the toxic organics are xenobiotic in character. In addition, when enzymes with low substrate specificity encounter foreign molecules, products that are xenobiotic often result. A mong the catalytic oxidation systems, two that have been studied most extensively are the titanium dioxide catalyzed photooxidations ${ }^{3}$ and the "Fenton"

systems involving hydrogen peroxide and a soluble transition metal catalyst. ${ }^{4}$ Again, although they have the advantages of broad substrate applicability and cleanliness, these systems are not optimal in many situations. For example, photons are relatively expensive and the photooxidation systems cannot be employed where there is a dearth of sunlight or where large volumes of contaminated water are involved. In Fenton oxidations, a portion of the hydrogen peroxide is wasted because of a parallel (metal catalyzed) decomposition pathway. Additionally, soluble catalysts that are usually used are difficult to remove following decontamination. Very recently, metal complexes of macrocyclic ligands have been used as catalysts in conjunction with the persulfate ion as the oxidant. ${ }^{5} \mathrm{~A}$ gain, the systems suffer from one or more drawbacks: (a) incomplete oxidation of the substrate, (b) use of expensiveligands and their eventual oxidative degradation, and (c) the use of expensive, oxidants. 


\section{METHODSAND RESULTS}

\section{A. Catalytic System}

We have previously described a catalytic system for the direct, low temperature, oxidation of

methane and lower al kanes. ${ }^{6}$ In this system, metallic palladium was found to catalyze the oxidation of alkanes, including methane, by dioxygen in aqueous medium at $70-100^{\circ} \mathrm{C}$ in the presence of carbon monoxide. While carboxylic acids are the initial products (and the reaction can be stopped at this stage by using a large amount of the starting alkane), the ultimate oxidation products are carbon monoxide and carbon dioxide. Using ethaneas a test substrate, over 1000 turnovers $(=\mathrm{mmol}$ of substrate reacted $/ \mathrm{mmol}$ of surface $\mathrm{Pd}$ atoms) were observed over a $24 \mathrm{~h}$ period at $90^{\circ} \mathrm{C}$. Mechanistic studies previously reported indicates that the overall transformation encompasses three catalytic steps in tandem (Scheme 1). ${ }^{6 a}$ The first is the water-gas shift reaction (WGSR) involving the oxidation of carbon monoxide to carbon dioxide with the simultaneous formation of dihydrogen. The second catalytic step involves the combination of dihydrogen with dioxygen to yield hydrogen peroxide (or its equivalent, $\mathrm{M}-\mathrm{OOH}$ ). ${ }^{7}$ The formation of hydrogen peroxide through palladium-catalyzed reaction between carbon monoxide, water, and dioxygen has also been the subject of several patent applications. ${ }^{8}$

The third step in the oxidation process involves the metal catalyzed oxidation of the substrate by the hydrogen peroxide equivalent. It is possible to replace carbon monoxide and dioxygen by hydrogen peroxide; however, unless the latter is added slowly (see below) the amount of substrate oxidized relative to the hydrogen peroxide consumed is low due to the catalytic decomposition of hydrogen peroxide occurring in parallel with the oxidation. It is this latter undesirable reaction that made the combination of carbon monoxide and dioxygen more effective than hydrogen peroxide. Starting with carbon monoxide and dioxygen, hydrogen peroxide is formed at a low steady rate through the first two catalytic reactions and is used more efficiently for substrate oxidation. This was verified by carrying out the oxidation of phenol under conditions similar to that shown in Table 1, except that the gas mixture was replaced by $50 \%$ hydrogen peroxide added slowly over a period of $24 \mathrm{~h}$ through a syringe pump. A $40 \%$ conversion of phenol was obtained which is only slightly lower than that observed with carbon monoxide-dioxygen mixture. The requirement of a coreductant (carbon monoxide) makes the overall reaction formally 
analogous to the monooxygenases in which only one of the two oxygen atoms in the dioxygen molecule is used for substrate oxidation. ${ }^{9}$

Scheme 1. Mechanism of Pd catalyzed oxidation of organic substrates.

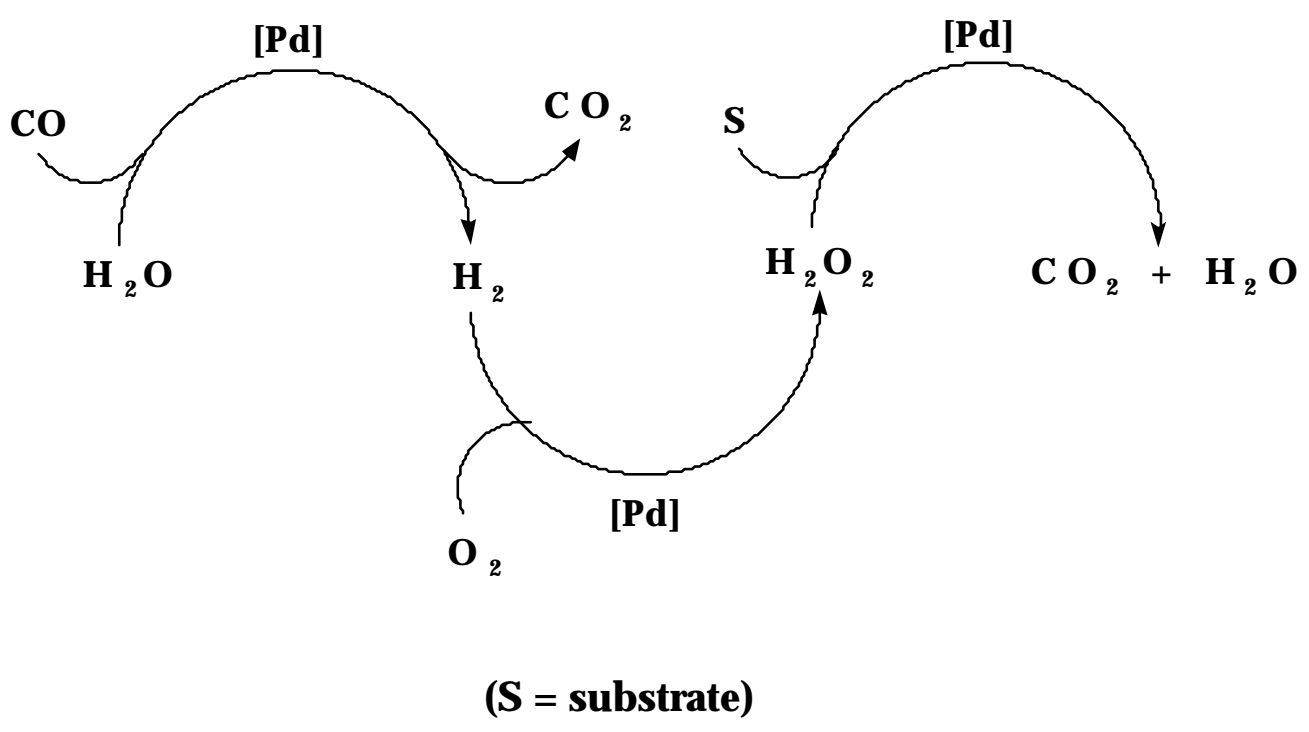

B. Oxidation of A romatics, $\mathrm{N}$ itro and Halo Organics $10-12$

\section{Scope}

Since the above catalytic system was able to effect the deep oxidation of molecules as unreactive as methane under unusually mild conditions, we have explored the ability of the system to catalyze the deep oxidation of hazardous organics. ${ }^{10-12}$ Several classes of organic compounds were examined: benzene, phenol and substituted phenols, nitro and halo organics, organophosphorus, and organosulfur compounds. Typical reaction conditions were as follows: substrate dissolved in $3 \mathrm{ml}$ of DCl acidified $\mathrm{D}_{2} \mathrm{O}, 5 \% \mathrm{Pd} /$ carbon $(60 \mu \mathrm{mol}$ surface Pd atoms/ g catalyst, as determined by dihydrogen chemisorption studies) as catalyst, $100 \mathrm{psi} \mathrm{O}_{2}, 100 \mathrm{psi} \mathrm{CO}, 1000 \mathrm{psi} \mathrm{N}_{2}, 80-90^{\circ} \mathrm{C}$. In every case, deep oxidation to carbon monoxide, carbon dioxide, and water occurred in high yields, resulting in up to several hundred turnovers over a $24 \mathrm{~h}$ period. N o catalysis was observed when carbon alonewas employed (although a small loss of 
reactants ( 10\%) was observed, presumably due to absorption). On the other hand, $5 \% \mathrm{Pd} / \mathrm{Al}_{2} \mathrm{O}_{3}$ was also found to be an active catalyst; however, the turnover rate was somewhat lower than that for $5 \%$ $\mathrm{Pd} /$ carbon. Thus, under similar reaction conditions, the conversions observed starting with $0.175 \mathrm{mmol}$ of $\mathrm{CH}_{3} \mathrm{CH}_{2} \mathrm{CH}_{2} \mathrm{SO}_{3} \mathrm{~N}$ a were $74 \%$ for $5 \% \mathrm{Pd} / \mathrm{Al}_{2} \mathrm{O}_{3}$ and $95 \%$ for $5 \% \mathrm{Pd} /$ carbon.

Phenol was found to bethe initial oxidation product of benzene. p-Benzoquinone, glycolic, and formic acids were formed subsequently. That these products arose from benzene (and not by the hydrogenation of carbon monoxide) was verified by starting with ${ }^{13} \mathrm{C}_{6} \mathrm{H}_{6}$ which lead to the formation of the corresponding ${ }^{13} \mathrm{C}$-labeled products. Because of the poor solubility of benzene in water, as described later, quantitative studies of benzene oxidation were carried out in a mixture of perfluorobutyric acid and water.

The deep oxidation of a number of para-substituted phenols was achieved under typical reaction conditions (Table 1 ). The products of the decomposition of p-bromophenol ( $25 \mathrm{mg}, 0.145 \mathrm{mmol}$ ) were examined by ${ }^{1}$ H N MR spectroscopy and were found to included p-benzoquinone $(0.08 \mathrm{mmol})$ and formic acid $(0.28 \mathrm{mmol})$. Trace amounts of acetic and glycolic acids were al so detected. The remainder of the pbromophenol was converted to $\mathrm{CO}_{\times}, \mathrm{H}_{2} \mathrm{O}$, and $\mathrm{Br}^{-}$. At longer reaction times, no organics were observed in solution from any of the substrates. A series of competition experiments were performed and the rate of conversion of substrate decreased with increasing electronegativity of the para-substituent, with an approximately linear correlation between the electron affinity of the substituent and the ratio of the log of the rate of oxidation of substituted phenol to the parent phenol. This is consistent with an initial electrophilic attack at the ring. While the exact nature of the electrophile remains to be elucidated, one possibility in analogy with monoxygenases is a metal-oxo species generated on the metal surface (see Conclusion).

Perhalogenated aromatics were also examined. 2,4,6-Trichlorophenol, a toxic byproduct from paper mills, was decomposed under similar reaction conditions. Of note is that trichlorophenol is poorly soluble in water and yet oxidation occurred. Starting with $25 \mathrm{mg}(0.13 \mathrm{mmol})$ of 2,4,6-trichlorophenol, $94 \%$ conversion was noted after $1 \mathrm{~d}$ ( 100 turnovers/ surface $\mathrm{Pd}$ atoms). The analysis was performed by examining the ${ }^{1} \mathrm{H}-\mathrm{NMR}$ spectra of both the aqueous layer and the $\mathrm{CDCl}_{3}$ extract. Trace amounts of acetic and formic acids were the only carbon containing products found. The chloride ions formed in solution were determined gravimetrically by precipitation with $\mathrm{AgNO}_{3}$. The results indicated that the chlorine atoms present in the substrate were quantitatively converted to chloride ions. 
In a similar manner 4,4'-bibromobiphenyl ( $25 \mathrm{mg}, 0.08 \mathrm{mmol}$ ) was oxidized with an $40 \%$ conversion to $\mathrm{CO}_{x}, \mathrm{H}_{2} \mathrm{O}$, and $\mathrm{Br}^{-}$( 35 turnovers/ surface $\mathrm{Pd}$ atoms). A gain, only traces of acetic and formic acid were detected by ${ }^{1}$ H N MR spectroscopy, and bromide ions were quantitatively determined by precipitation with $\mathrm{AgNO}_{3}$.

Although the catalytic system described above exhibits many attractive features, one potential problem is that many toxic organics are insoluble in water and therefore arelikely to be oxidized very slowly under typical reaction conditions. Consequently, we have briefly examined alternative solvent systems that are superior to water in dissolving organic compounds. One such solvent system (which is not, however, useful from a practical standpoint) consists of a mixture of water and perfluorobutyric acid, and $\mathrm{CH}_{3} \mathrm{CH}_{2} \mathrm{CH}_{2} \mathrm{SO}_{3} \mathrm{~N}$ a was used as the test substrate $(125 \mathrm{mg}, 0.76 \mathrm{mmol})$. The maximum rate was achieved at $50 \%(\mathrm{v} / \mathrm{v})$ perfluorobutyric acid:water mixture with a $98 \%$ conversion of the substrate (500 turnovers/ surface Pd atoms). Beyond 60\% (v/ v) perfluorobutyric acid, the reaction rate decreased sharply presumably because water was necessary for the generation of hydrogen peroxide (Scheme 1).

The 50\% (v/ v) perfluorobutyric acid:water mixture was used as the solvent to carry out the deep oxidation of two substrates that are poorly soluble in water al one: benzene and 1,1,2,2-tetrachloroethane. Under typical reaction conditions, starting with $0.5 \mathrm{mmol}$ of benzene in $3 \mathrm{ml}$ of solvent mixture, 435 turnovers/ surface $\mathrm{Pd}$ atoms to $\mathrm{CO}_{\mathrm{X}}$ and $\mathrm{H}_{2} \mathrm{O}$ were observed in a $24 \mathrm{~h}$ period. Traces of formic and glycolic acids were the only organic products observed in solution. In the case of 1,1,2,2tetrachloroethane, 35 turnovers/ surface Pd atoms were observed as determined by gravimetric chloride analysis.

\section{Use of Carbon M onoxide-D ioxygen M ixture versus D ihydrogen-D ioxygen M ixture ${ }^{12}$}

Since the function of the added carbon monoxide in the above system is to generate dihydrogen (Scheme 1), an interesting issue involves the comparison of oxidation rates starting with dioxygen and dihydrogen versus dioxygen and carbon monoxide. Clearly, the rate in the first case should be equal to or higher than that observed with the latter combination. The issue is further complicated by the question of whether in the case of aromatic substrates a prereduction step facilitates the subsequent deep oxidation. Accordingly, we have examined the effect of added dihydrogen versus carbon monoxide in the deep oxidation of nitro and hal oaromatics. ${ }^{12} \mathrm{~N}$ itroaromatics are a major class of ground water and soil 
contaminants because of their use as pesticides (e. g., 2-sec-butyl-4,6-dinitrophenol, trade name: dinoseb) and explosives (e. g., di and trinitrotoluene). ${ }^{13}$ These compounds persist in the soil for many years. ${ }^{14}$ Hal oorganic contaminants stem from their use as degreasing solvents, pesticides, herbicides, and heat transfer fluids. Again, the bioremediation of these compounds is an extremely slow process. ${ }^{2}$

As can be seen from Table 2, efficient oxidative degradation of substrates occurred when either dihydrogen or carbon monoxide was used as the coreductant. However, where there is a difference, lower substrate decomposition was al most invariably observed using carbon monoxide as the coreductant. This trend became more obvious when the reactions were carried out at lower conversion (Table 3). N ote that no reaction occurred when the coreductant was absent. There was no reaction either when carbon monoxide but not dioxygen was present. On the other hand, near quantitative reduction to cyclohexane derivatives occurred when dihydrogen but not dioxygen was present in the reaction mixture. Additionally, for nitrogen-containing substrates, the formation of ammonium ion was observed. It is clear from these experiments that while the prior reduction of the substrate isnot a requirement for its oxidative degradation, such a step may enhance the decomposition rate, as is evident from the comparison of the reactions involving dihydrogen and carbon monoxide as coreductants. Interestingly, however, aniline was slower to react than either nitro or nitroso benzene and is, therefore, not an intermediate in the oxidation of the latter substrates (see Table 2 and 3). Presumably, aniline is protonated in the reaction medium and the resultant electron-withdrawing anilinium group deactivates the ring towards electrophilic attack.

In all oxidations involving nitrogen-containing substrates, the ammonium ion was detected by 1H-N MR spectroscopy ${ }^{15}$ and in many cases the nitrate was also detected (Table 2). However the combined amount these two products was significantly lower than the total nitrogen in the substrate, thereby indicating that other nitrogen-containing species were also generated in the reactions (for example, $\mathrm{NH}_{4} \mathrm{NO}_{3}$ is known to decompose thermally to $\mathrm{N}_{2} \mathrm{O}$ and water). $\mathrm{No}$ ammonia gas was detected by GC analysis in the head space of the reactor after the reaction of p-nitrophenol under standard conditions in the presence of $100 \mathrm{psi}$ of dihydrogen. In order to determine if partial decomposition of the ammonium ion was occurring following its formation, a control reaction using $\mathrm{NH}_{4} \mathrm{Cl}(1 \mathrm{mmol})$ as the substrate was conducted in $1: 1 \mathrm{H}_{2} \mathrm{O} / \mathrm{CF}_{3} \mathrm{CO}_{2} \mathrm{H}$. Some decomposition (approx. 20\%) of the ammonium ion was observed by ${ }^{1} \mathrm{H}-\mathrm{N}$ MR spectroscopy. A pproximately half of this decomposition was to the nitrate ion. The use of $\mathrm{NaNO}_{3}(1 \mathrm{mmol})$ as the substrate under standard conditions afforded no ammonium ion, 
thereby indicating that the ammonium was not produced from an intermediate nitrateion. Additionally, starting with $\mathrm{NaNO}_{3}$, neither ammonia nor the ammonium ion was detected by $\mathrm{GC}$ analysis and ${ }_{\mathrm{H}}$ NMR spectroscopy, respectively, when an organic hydrogen source, phenol ( $1 \mathrm{mmol})$, was added or when dioxygen was removed from the reaction mixture.

The $\mathrm{pH}$ and the composition of the solvent appears to have a significant effect on the oxidative degradation of the above substrates. For example, using the dihydrogen/ dioxygen mixture, substituting $\mathrm{H}_{2} \mathrm{SO}_{4}$ for $\mathrm{HCl}$ but maintaining a $\mathrm{pH}=1$ resulted in a similar oxidation rate for 1,3-dinitrobenzene. On the other hand, a significantly lower conversion rate was observed in neutral water. The use of pure $\mathrm{CF}_{3} \mathrm{CO}_{2} \mathrm{H}$ resulted in reduced oxidation and formation of cyclohexane derivatives and ammonium ion from 1,3-dinitrobenzene by hydrogenation/ hydrogenolysis. On the other hand, the use of a 1: 1 (v/ v) mixture of $\mathrm{CF}_{3} \mathrm{CO}_{2} \mathrm{H}$ and water resulted in efficient substrate oxidation that was generally comparable to $\mathrm{HCl}$-acidified water (Table4). The former solvent system was, however, significantly superior for substrates that are poorly soluble in water, such as 1,3-dinitrobenzene.

Finally, an alternate explanation for the increase in substrate oxidation rate with dihydrogen/ dioxygen mixture over carbon monoxide/ dioxygen mixture may be that hydrogen simply produces a higher concentration of hydrogen peroxide (see Scheme 1). However, a comparison of the two systems for substrates for which hydrogenation is unlikely appears to rule out this possibility. Thus, for a series of organic phosphorus and sulfur compounds similar (or lower) oxidation rates were observed for the dihydrogen/ dioxygen mixture(Table5).

The most likely explanation for the superiority of the dihydrogen-dioxygen mixture over carbon monoxide-dioxygen mixture for the deep oxidation of aromatics is that the observed prereduction by dihydrogen converts the stronger $\mathrm{sp}^{2} \mathrm{C}-\mathrm{H}$ bonds to weaker $\mathrm{sp}^{3} \mathrm{C}-\mathrm{H}$ bonds (e. g., the $\mathrm{C}-\mathrm{H}$ bond energy is $\sim 15 \mathrm{kcal}$ lower in cyclohexane compared to benzene), thereby facilitating there subsequent activation and oxidation.

\section{Oxidation of Organophosphorus and Sulfur Compounds ${ }^{11}$}

Oxidation of trimethylphosphine oxide produced three phosphorus containing products: dimethyl phosphinic acid, methylphosphonic acid, and phosphoric acid (Table 6). These resulted from the 
cleavage of one, two, and three phosphorus-carbon bonds, respectively. The methyl groups were oxidized to form formic acid and ultimately $\mathrm{CO}_{2}$. Dimethylphosphinic acid and methylphosphonic acid are intermediates in the formation of phosphoric acid. After $179 \mathrm{~h}$, only a trace of $\left(\mathrm{CH}_{3}\right)_{3} \mathrm{PO}$ remained. In $179 \mathrm{~h}$, over 4000 phosphorus-carbon bonds w ere cleaved by each Pd! A study of the kinetics of both dimethylphosphinic acid and methylphosphonic acid oxidation indicated a zero-order relationship between reaction rate and substrate concentration. Such a relationship is ideal in the context of efficient oxidation of substrates down to low concentrations. M ore significantly, both substrates appear to be oxidized at similar rates thereby indicating that other substituents present on the phosphorus had little effect on the rate (Tables 7 and 8). In order to ascertain whether the final product, orthophosphate, inhibited the oxidation, the oxidation of $1 \mathrm{mmol}$ of trimethylphosphine oxide was carried out under identical conditions with and without the addition of $1 \mathrm{mmol}$ of $\mathrm{NaH}_{2} \mathrm{PO}_{4}$. A $25 \%$ reduction in rate was observed in the presence of the phosphate.

The oxidation of triethylphosphine oxide led to ten phosphorus containing products. Partial oxidation of the ethyl groups competed with phosphorus-carbon cleavage. The phosphorus-containing products derived from phosphorus-carbon cleavage that were identified were diethylphosphinic acid, ethylphosphonic acid, and phosphoric acid. In addition phosphonoacetic acid was identified as a product derived from the partial oxidation of an ethyl group. Other organic products derived from the oxidation of the ethyl group that were present in solution were acetic and formic acids. After $128.5 \mathrm{~h}$, no starting material remained, and the major phosphorus-containing products were phosphonoacetic acid, ethylphosphonic acid, and phosphoric acid. A separatestudy of ethylphosphonic acid oxidation showed that phosphorus-carbon cl eavage was si gnificantly favored over carbon-hydrogen cleavage and oxidation (Table 9). From the ratio of $\mathrm{H}_{3} \mathrm{PO}_{4}$ to $\mathrm{HO}_{2} \mathrm{CCH}_{2} \mathrm{P}(\mathrm{O})(\mathrm{OH})_{2}$, it can be estimated that the relative phosphorus-carbon to carbon-hydrogen cleavage was 5.6 on a per bond basis. However, this number is subject to error since phosphonoacetic acid itself was efficiently oxidized to phosphoric acid. For example, when phosphonoacetic acid $(0.71 \mathrm{mmol})$ was oxidized under standard conditions for $16 \mathrm{~h}$, a $46 \%$ conversion to phosphoric acid resulted.

By simple filtration, the catalyst could be retrieved and reused with no significant loss in activity. For example, $85.3 \%$ of $\left(\mathrm{CH}_{3}\right) 3 \mathrm{PO}(0.54 \mathrm{mmol})$ was oxidized in $20 \mathrm{~h}$. Removal of the catalyst by filtration and subsequent reuse resulted in the oxidation of $78.6 \%$ of $\left(\mathrm{CH}_{3}\right)_{3} \mathrm{PO}(0.54 \mathrm{mmol})$ in $20 \mathrm{~h}$. The small loss in activity was most likely due to loss of catalyst during filtration. 
The deep oxidation of sulfur-containing analogs to mustard gas, $\left(\mathrm{ClCH}_{2} \mathrm{CH}_{2}\right)_{2} \mathrm{~S}$, occurred readily with the bulk of the substrate being converted to carbon monoxide, carbon dioxide, and water (Table 10). A 1:1 (v/ v) mixture of water and perfluorobutyric acid was used in order to enhance the solubility of the substrate. Starting with dimethylsulfide $(1.00 \mathrm{mmol})$, the species observed in solution after $17 \mathrm{~h}$ of reaction were dimethylsulfoxide $(0.22 \mathrm{mmol})$, methanesulfonic acid $(0.04 \mathrm{mmol})$, and formic acid $(0.26$ $\mathrm{mmol})$. Dimethylsulfoxide $(0.5 \mathrm{mmol})$ itself was converted to methanesulfonic acid $(0.14 \mathrm{mmol})$, and dimethylsulfone $(0.30 \mathrm{mmol})$ after $18 \mathrm{~h}$. To determine if dimethylsulfone was an intermediate in the oxidation of dimethylsulfoxide to methanesulfonic acid, the products from oxidation of dimethylsulfoxide ( $2 \mathrm{mmol})$ and the oxidation of a mixture of dimethylsulfoxide $(1 \mathrm{mmol})$ and dimethylsulfone ( $1 \mathrm{mmol}$ ) was analyzed. Since the yield of methanesulfonic acid was similar in both reactions $(0.59,0.53 \mathrm{mmols}$, respectively), it is evident that dimethylsulfone was not an intermediate in the oxidation of dimethylsulfoxide to methanesulfonic acid. Unlike dimethylsulfide and dimethylsulfoxide, dimethylsulfone and methanesulfonic acid were particularly resistant to oxidation. Starting with $0.5 \mathrm{mmol}$ of substrate, over $90 \%$ of the substrate remained unreacted in each case after $18 \mathrm{~h}$. The ease of oxidation decreased in the order: $\left(\mathrm{CH}_{3}\right)_{2} \mathrm{~S}>\left(\mathrm{CH}_{3}\right)_{2} \mathrm{SO}>\left(\mathrm{CH}_{3}\right)_{2} \mathrm{SO}_{2}$ and further supports the conclusion that the system acts as an electrophilic oxidant.

The ethyl analogs showed a similar reactivity pattern. Starting with diethyl sulfide $(1.00 \mathrm{mmol})$, the species observed in solution after $28 \mathrm{~h}$ of reaction were: diethylsulfoxide $(0.13 \mathrm{mmol})$ and unreacted diethyl sulfide $(0.42 \mathrm{mmol})$. Diethyl sulfone $(0.82 \mathrm{mmol})$ was much more reactive than its methyl analog and after $16.5 \mathrm{~h}$ of reaction the species present in solution were: ethanesulfonic acid $(0.15 \mathrm{mmol})$, acetic acid $(0.08 \mathrm{mmol})$, formic acid $(0.13 \mathrm{mmol})$, al ong with unreacted sulfone $(0.60 \mathrm{mmol})$. After $20.5 \mathrm{~h}$ of reaction time the following species were observed in solution starting with ethane sulfonic acid ( 0.2 $\mathrm{mmol})$ : methylsulfate $(0.03 \mathrm{mmol})$, acetic acid $(0.06 \mathrm{mmol})$, formic acid $(0.12 \mathrm{mmol})$, al ong with unreacted starting material $(0.03 \mathrm{mmol})$.

\section{CONCLUSION}

In conclusion, we have discovered an unusual ly versatile catalytic system for the deep oxidation of toxic organics in water. This system possesses several attractive features not found simultaneously in other reported systems. These are (a) the ability to directly utilize dioxygen as the oxidant, (b) the ability to carry out the deep oxidation of a particularly wide range of functional organics, and (c) the ease of recovery of the catalyst by simplefiltration. 
While our understanding of the mechanistic steps involved in the overall oxidation is far from complete, it is clear that a powerful el ectrophilic oxidant is generated in situ. One possibility is a metaloxo species generated on the metal surface through the sequence of steps outlined in eq. 1. An initial metal-hydride is expected to form through the water-gas shift reaction or by direct reaction with dihydrogen. Such a species is known to react with dioxygen to form a metal-hydroperoxide, ${ }^{16}$ which can be subsequently protonated to release water and form the metal oxo-species (hence the requirement of an acid). The sequence of steps is precedented and bears resemblance to that occurring in monoxygenases. ${ }^{9}$

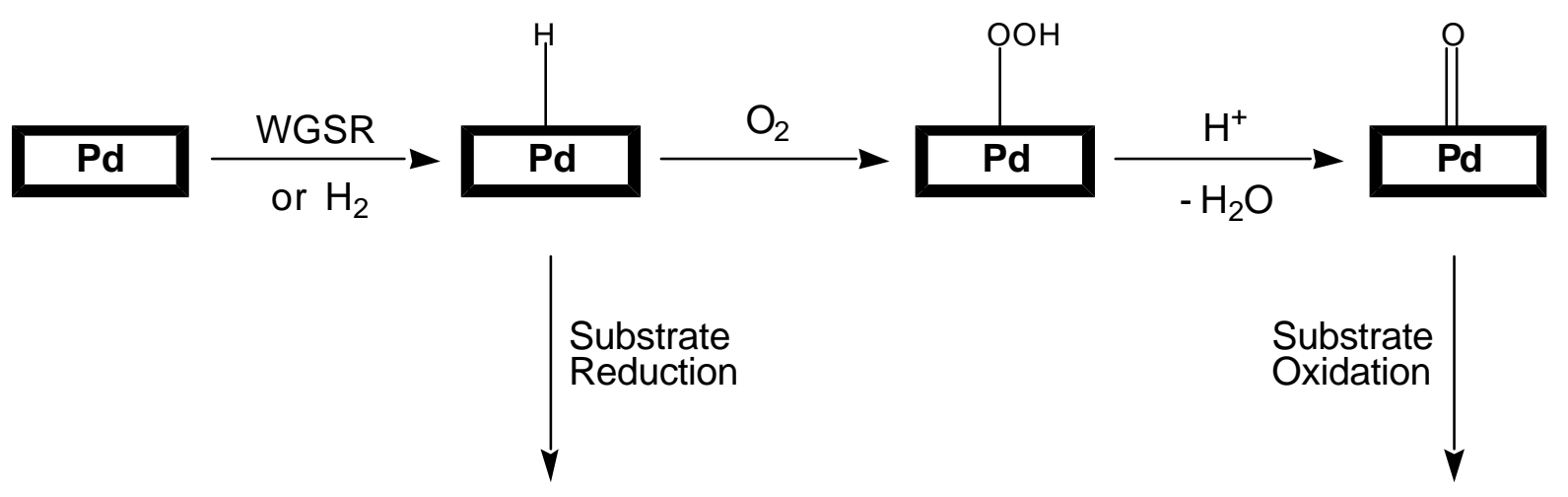

(1) 
Table 1. Oxidation for para-substituted phenols. ${ }^{1}$

\begin{tabular}{|llll|}
\hline Substrate & $\begin{array}{l}\text { Substrate } \\
\text { (mmol) }\end{array}$ & Conversion (\%) & $\begin{array}{l}\text { Turnovers/ } \\
\text { surface Pd }\end{array}$ \\
\hline p-nitrophenol & 0.18 & 10 & 20 \\
p-chlorophenol & 0.20 & 17 & 37 \\
p-bromophenol & 0.15 & 78 & 125 \\
p-iodophenol & 0.11 & 94 & 119 \\
phenol & 0.27 & 46 & 137 \\
\hline
\end{tabular}

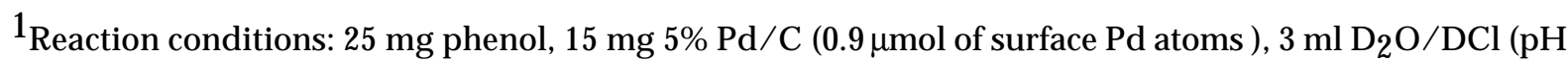
=3), 100 psi CO, 1000 psi N $2,100 \mathrm{psi}_{2}, 90^{\circ} \mathrm{C}, 24 \mathrm{~h}$. 
Table 2. Oxidation of $\mathrm{N}$ itro and Haloaromatics. ${ }^{1}$

\begin{tabular}{|c|c|c|c|c|}
\hline Substrate & $\begin{array}{l}\text { Conversion } \\
\text { with } \mathrm{H}_{2} / \mathrm{O}_{2}\end{array}$ & $\begin{array}{l}\text { Conversion } \\
\text { with } \mathrm{CO} / \mathrm{O}_{2}\end{array}$ & $\begin{array}{l}\text { Side Products } \\
\text { with } \mathrm{H}_{2} / \mathrm{O}_{2} \text { (mmol) }\end{array}$ & $\begin{array}{l}\text { Side Products } \\
\text { with } \mathrm{CO} / \mathrm{O}_{2}(\mathrm{mmol})\end{array}$ \\
\hline nitromethane & $94 \%$ & $86 \%$ & $\begin{array}{l}\text { ammonium (0.01) } \\
\text { nitrate }(>0.04) \\
\text { formic acid }(0.06)\end{array}$ & $\begin{array}{l}\text { ammonium }(0.01) \\
\text { nitrate }(>0.04) \\
\text { formic acid }(0.02)\end{array}$ \\
\hline p-nitrophenol & $99+\%$ & $99+\%$ & $\begin{array}{l}\text { ammonium }(0.10) \\
\text { nitrate }(<0.04) \\
\text { formic acid (tr) }\end{array}$ & $\begin{array}{l}\text { ammonium }(0.06) \\
\text { nitrate }(>0.08) \\
\text { formic acid }(0.21)\end{array}$ \\
\hline m-nitrophenol & $99+\%$ & $99+\%$ & $\begin{array}{l}\text { ammonium (0.06) } \\
\text { nitrate }(<0.04) \\
\text { formic acid (tr) }\end{array}$ & $\begin{array}{l}\text { ammonium }(0.06) \\
\text { nitrate }(>0.08) \\
\text { formic acid }(0.07)\end{array}$ \\
\hline nitrobenzene & $99+\%$ & $98 \%$ & $\begin{array}{l}\text { ammonium (0.07) } \\
\text { nitrate }(<0.04) \\
\text { formic acid (tr) }\end{array}$ & $\begin{array}{l}\text { ammonium (0.04) } \\
\text { nitrate }(>0.08) \\
\text { formic acid }(0.08)\end{array}$ \\
\hline nitrosobenzene & $99+\%$ & $99+\%$ & $\begin{array}{l}\text { ammonium }(0.02) \\
\text { nitrate }(>0.08) \\
\text { formic acid }(0.06)\end{array}$ & $\begin{array}{l}\text { ammonium (0.09) } \\
\text { nitrate (<0.04) } \\
\text { formic acid (tr) } \\
\text { aminophenol (0.04) } \\
\text { aniline (0.01) } \\
\text { hydroquinone (tr) }\end{array}$ \\
\hline azobenzene & $96 \%$ & $85 \%$ & $\begin{array}{l}\text { ammonium (0.04) } \\
\text { nitrate }(\varangle 0.04) \\
\text { aniline }(0.02)\end{array}$ & $\begin{array}{l}\text { ammonium (0.03) } \\
\text { nitrate }(\varangle 0.04) \\
\text { formic acid }(0.01) \\
\text { aniline }(0.02) \\
\text { hydroquinone (tr) }\end{array}$ \\
\hline aniline & $62 \%$ & $87 \%$ & $\begin{array}{l}\text { ammonium (0.05) } \\
\text { nitrate }(\varangle 0.04) \\
\text { formic acid (tr) }\end{array}$ & $\begin{array}{l}\text { ammonium }(0.07) \\
\text { nitrate }(<0.04) \\
\text { formic acid }(0.08)\end{array}$ \\
\hline 1,2-dinitrobenzene & $98 \%$ & $99 \%$ & $\begin{array}{l}\text { ammonium }(0.10) \\
\text { nitrate }(\varangle 0.04)\end{array}$ & $\begin{array}{l}\text { ammonium }(0.05) \\
\text { nitrate }(>0.04) \\
\text { formic acid }(0.04)\end{array}$ \\
\hline 1,4-dinitrobenzene & $99 \%$ & $88 \%$ & ammonium (0.14) & ammonium (tr) \\
\hline
\end{tabular}




\begin{tabular}{|c|c|c|c|c|}
\hline & & & nitrate $(>0.08)$ & nitrate $(<0.04)$ \\
\hline & & & formic acid (tr) & formic acid (tr) \\
\hline 1,3-dinitrobenzene & $73 \%$ & $77 \%$ & ammonium (0.10) & ammonium (0.01) \\
\hline & & & nitrate $(<0.04)$ & nitrate $(<0.04)$ \\
\hline & & & & formic acid (0.05) \\
\hline 1-chloro-3-nitrobenzene & $99+\%$ & $86 \%$ & ammonium (0.08) & ammonium (0.02) \\
\hline & & & nitrate $(<0.04)$ & nitrate $(>0.08)$ \\
\hline & & & formic acid (0.04) & formic acid (0.03) \\
\hline & & & aniline (0.06) & \\
\hline 1-chloro-4-nitrobenzene & $80 \%$ & $85 \%$ & ammonium (0.03) & ammonium (0.02) \\
\hline & & & nitrate $(>0.08)$ & nitrate $(>0.04)$ \\
\hline & & & formic acid (0.06) & formic acid (0.03) \\
\hline p-chlorophenol & $96 \%$ & $92 \%$ & formic acid (0.01) & formic acid (0.09) \\
\hline & & & & hydroquinone (0.06) \\
\hline m-chlorophenol & $99+\%$ & $89 \%$ & formic acid (0.02) & formic acid (0.09) \\
\hline p-bromophenol & $99+\%$ & $99 \%$ & formic acid (0.08) & formic acid (0.08) \\
\hline & & & & hydroquinone (0.03) \\
\hline & & & & p-hydroxybenzoic acid \\
\hline & & & & $(0.04)$ \\
\hline m-bromophenol & $99+\%$ & $99+\%$ & formic acid (0.09) & formic acid (0.04) \\
\hline & & & hydroquinone (tr) & m-hydroxybenzoic acid \\
\hline & & & & $(0.08)$ \\
\hline
\end{tabular}

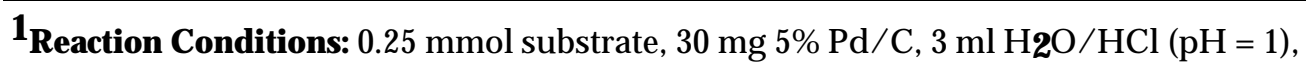

100 psi H 2 or CO, 1000 psi N 2, 100 psi O2, $130^{\circ} \mathrm{C}, 16 \mathrm{~h}$. 
Table 3: Comparison of $\mathrm{CO} / \mathrm{O} 2$ vs. $\mathrm{H}_{2 / 0} 2$ at Lower Conversions. ${ }^{1}$

\begin{tabular}{|c|c|c|c|c|}
\hline Substrate & $\begin{array}{l}\text { Conversion } \\
\text { with } \mathrm{H}_{2} / \mathrm{O}_{2}\end{array}$ & $\begin{array}{l}\text { Conversion } \\
\text { with } \mathrm{CO} / \mathrm{O}_{2}\end{array}$ & $\begin{array}{l}\text { Side Products } \\
\text { with } \mathrm{H}_{2} / \mathrm{O}_{2} \text { (mmol) }\end{array}$ & $\begin{array}{l}\text { Side Products } \\
\text { with } \mathrm{CO} / \mathrm{O} 2(\mathrm{mmol})\end{array}$ \\
\hline p-nitrophenol & $79 \%$ & $31 \%$ & $\begin{array}{l}\text { ammonium (0.04) } \\
\text { formic acid (0.06) } \\
\text { hydroquinone (0.07) }\end{array}$ & $\begin{array}{l}\text { ammonium (tr) } \\
\text { formic acid (0.03) } \\
\text { hydroquinone (0.04) }\end{array}$ \\
\hline p-chlorophenol & $89 \%$ & $57 \%$ & $\begin{array}{l}\text { formic acid (0.09) } \\
\text { phenol }(0.17)\end{array}$ & $\begin{array}{l}\text { formic acid }(0.03) \\
\text { hydroquinone }(0.10)\end{array}$ \\
\hline $\begin{array}{l}\text { aniline } \\
\text { nitrobenzene }\end{array}$ & $\begin{array}{l}38 \% \\
92 \%\end{array}$ & $\begin{array}{l}16 \% \\
67 \%\end{array}$ & $\begin{array}{l}\text { unidentified } \\
\text { ammonium (0.11) } \\
\text { aniline (0.28) } \\
\text { hydroquinone (0.01) }\end{array}$ & $\begin{array}{l}\text { unidentified } \\
\text { ammonium (0.03) } \\
\text { formic acid (0.13) }\end{array}$ \\
\hline
\end{tabular}

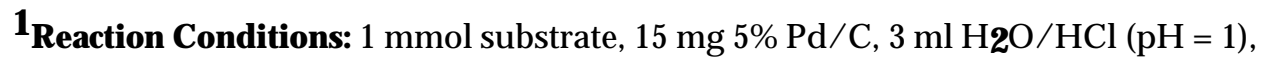

100 psi H 2 or CO, 1000 psi N 2, 100 psi O2, $90^{\circ} \mathrm{C}, 16 \mathrm{~h}$. 
Table 4. Oxidation of Nitroaromatics in $\mathrm{CF}_{3} \mathrm{CO}_{2} \mathrm{H} / \mathrm{H}_{2} \mathrm{O}^{1}$

\begin{tabular}{|c|c|c|}
\hline Substrate & $\begin{array}{l}\text { Conversion } \\
\text { with } \mathrm{H}_{2} / \mathrm{O}_{2}\end{array}$ & $\begin{array}{l}\text { Side Products } \\
\text { with } \mathrm{H}_{2} / \mathrm{O}_{2} \text { (mmol) }\end{array}$ \\
\hline 1,4-dinitrobenzene & $99+\%$ & $\begin{array}{l}\text { ammonium }(0.35) \\
\text { nitrate }(>0.08)\end{array}$ \\
\hline 1,2-dinitrobenzene & $99+\%$ & $\begin{array}{l}\text { ammonium }(0.32) \\
\text { nitrate }(<0.04) \\
\text { formic acid }(0.03)\end{array}$ \\
\hline 1,3-dinitrobenzene & $99+\%$ & $\begin{array}{l}\text { ammonium }(0.20) \\
\text { nitrate }(<0.04) \\
\text { formic acid (tr) }\end{array}$ \\
\hline
\end{tabular}

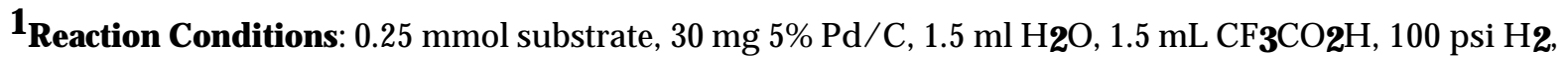
1000 psi N 2, 100 psi $02,150^{\circ} \mathrm{C}, 16 \mathrm{~h}$. 
Table 5. Oxidation of Phosphorus and Sulfur Compounds. ${ }^{1}$

\begin{tabular}{|c|c|c|c|c|}
\hline Substrate & $\begin{array}{l}\text { Conversion } \\
\text { with } \mathrm{H}_{2} / \mathrm{O}_{2}\end{array}$ & $\begin{array}{l}\text { Conversion } \\
\text { with } \mathrm{CO} / \mathrm{O}_{2}\end{array}$ & $\begin{array}{l}\text { Side Products } \\
\text { with } \mathrm{H}_{2} / \mathrm{O}_{2} \text { (mmol) }\end{array}$ & $\begin{array}{l}\text { Side Products } \\
\text { with } \mathrm{CO} / \mathrm{O} 2 \text { (mmol) }\end{array}$ \\
\hline \multirow[t]{3}{*}{$\begin{array}{l}\text { trimethylphosphine } \\
\text { oxide }\end{array}$} & $15 \%$ & $40 \%$ & $\begin{array}{l}\text { dimethyl phosphinic acid } \\
(0.14)\end{array}$ & $\begin{array}{l}\text { dimethylphosphinic acid } \\
(0.34)\end{array}$ \\
\hline & & & methylphosphonic acid (tr) & $\begin{array}{l}\text { methylphosphonic acid } \\
(0.06)\end{array}$ \\
\hline & & & formic acid (tr) & formic acid (tr) \\
\hline \multirow[t]{2}{*}{ dimethylphosphinic acid } & $16 \%$ & $11 \%$ & methylphosphonic acid (0.15) & $\begin{array}{l}\text { methylphosphonic acid } \\
(0.11)\end{array}$ \\
\hline & & & formic acid (tr) & formic acid (0.27) \\
\hline methylphosphonic acid & $5 \%$ & $10 \%$ & formic acid (tr) & formic acid (0.15) \\
\hline \multirow[t]{3}{*}{ dimethyl sulfide } & $66 \%$ & $61 \%$ & dimethylsulfoxide (0.02) & dimethylsulfoxide (0.22) \\
\hline & & & formic acid (tr) & dimethylsulfone (0.04) \\
\hline & & & & formic acid (tr) \\
\hline dimethylsulfone ${ }^{2}$ & $9 \%$ & $6 \%$ & dimethylsulfoxide (0.03) & methylsulfoxide (0.05) \\
\hline
\end{tabular}

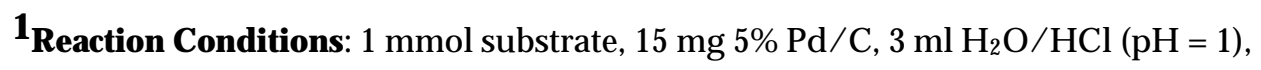

100 psi H 2 or CO, 1000 psi N 2, 100 psi $02,90^{\circ} \mathrm{C}, 20$ h. ${ }^{2} 0.5$ mmol substrate 
Table 6. Oxidation of trimethylphosphine oxide. ${ }^{1}$

\begin{tabular}{|c|c|c|c|c|c|c|}
\hline Time (h) & $\begin{array}{l}\left(\mathrm{CH}_{3}\right)_{3} \mathrm{PO} \\
(\mathrm{mmol})\end{array}$ & $\begin{array}{l}\left(\mathrm{CH}_{3}\right)_{2} \mathrm{P}(\mathrm{O})(\mathrm{OH}) \\
(\mathrm{mmol})\end{array}$ & $\begin{array}{l}\left(\mathrm{CH}_{3}\right) \mathrm{P}(\mathrm{O})(\mathrm{OH})_{2} \\
(\mathrm{mmol})\end{array}$ & $\begin{array}{l}\mathrm{H}_{3} \mathrm{PO}_{4} \\
(\mathrm{mmol})\end{array}$ & $\begin{array}{l}\mathrm{HCO}_{2} \mathrm{H} \\
(\mathrm{mmol})\end{array}$ & $\operatorname{TON}^{2}$ \\
\hline 0.00 & 5.43 & 0.00 & 0.00 & 0.00 & 0.00 & 0 \\
\hline 15.75 & 4.07 & 1.25 & 0.19 & 0.00 & 2.21 & 543 \\
\hline 39.0 & 2.06 & 2.06 & 1.31 & 0.00 & 5.00 & 1560 \\
\hline 68.0 & 1.11 & 2.51 & 1.58 & 0.22 & 5.16 & 2110 \\
\hline 92.0 & 0.51 & 2.09 & 2.26 & 0.56 & 4.48 & 2763 \\
\hline 109.5 & 0.25 & 1.67 & 2.57 & 0.93 & 3.27 & 3200 \\
\hline 157.5 & 0.07 & 1.00 & 2.68 & 1.68 & 2.35 & 3800 \\
\hline 179.0 & 0.04 & 0.72 & 2.57 & 2.10 & 2.22 & 4053 \\
\hline
\end{tabular}

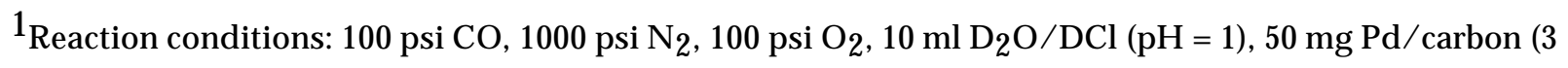

$\mu$ mol surface $\mathrm{Pd}$ atoms), $500 \mathrm{mg}\left(\mathrm{CH}_{3}\right)_{3} \mathrm{PO}(5.43 \mathrm{mmol}), 90^{\circ} \mathrm{C} .{ }^{2}$ Turnover number defined as

$\left\{\left(\mathrm{CH}_{3}\right)_{2} \mathrm{P}(\mathrm{O})(\mathrm{OH})\right]+2\left[\left(\mathrm{CH}_{3}\right) \mathrm{P}(\mathrm{O})(\mathrm{OH})_{2}\right]+3\left[\mathrm{H}_{3} \mathrm{PO}_{4}\right] y$ [surface $\mathrm{Pd}$ atoms] 
Table 7. Oxidation of dimethylphosphinic acid. ${ }^{1}$

\begin{tabular}{|c|c|c|c|c|c|}
\hline $\begin{array}{l}\text { Time } \\
\text { (h) }\end{array}$ & $\begin{array}{l}\left(\mathrm{CH}_{3}\right)_{2} \mathrm{P}(\mathrm{O}) \mathrm{OH} \\
(\mathrm{mmol})\end{array}$ & $\begin{array}{l}\left(\mathrm{CH}_{3}\right) \mathrm{P}(\mathrm{O})(\mathrm{OH})_{2} \\
(\mathrm{mmol})\end{array}$ & $\begin{array}{l}\mathrm{H}_{3} \mathrm{PO}_{4} \\
(\mathrm{mmol})\end{array}$ & $\begin{array}{l}\mathrm{HCO}_{2} \mathrm{H} \\
(\mathrm{mmol})\end{array}$ & $\operatorname{TON}^{2}$ \\
\hline 0 & 1.00 & 0.00 & 0.00 & 0.00 & 0 \\
\hline 18 & 0.89 & 0.11 & 0.00 & 0.27 & 122 \\
\hline 38 & 0.81 & 0.18 & 0.01 & 0.21 & 222 \\
\hline 59.5 & 0.73 & 0.25 & 0.02 & 0.66 & 322 \\
\hline
\end{tabular}

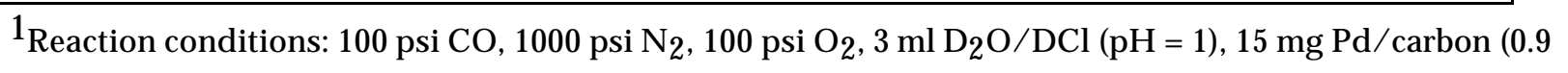

$\mu$ mol surface $\mathrm{Pd}$ atoms), $94 \mathrm{mg}\left(\mathrm{CH}_{3}\right)_{2} \mathrm{P}(\mathrm{O}) \mathrm{OH}(1.00 \mathrm{mmol}), 90^{\circ} \mathrm{C} .{ }^{2}$ Turnover number defined as $\left\{\mathrm{CH}_{3} \mathrm{P}(\mathrm{O})(\mathrm{OH})_{2}\right]+2\left[\mathrm{H}_{3} \mathrm{PO}_{4}\right]$ y [surface Pd atoms] 
Table 8. Oxidation of methyl phosphonic acid. ${ }^{1}$

\begin{tabular}{|lllll|}
\hline $\begin{array}{l}\text { Time } \\
\text { (h) }\end{array}$ & $\begin{array}{l}\left(\mathrm{CH}_{3}\right) \mathbf{P}(\mathbf{O})(\mathbf{O H})_{\mathbf{2}} \\
(\mathbf{m m o l})\end{array}$ & $\begin{array}{l}\mathrm{H}_{3} \mathrm{PO}_{\mathbf{4}} \\
(\mathbf{m m o l})\end{array}$ & $\begin{array}{l}\mathrm{HCO}_{2} \mathbf{H} \\
(\mathbf{m m o l})\end{array}$ & TO N $^{2}$ \\
\hline 0 & 1.00 & 0.00 & 0.00 & 0 \\
18 & 0.90 & 0.10 & 0.15 & 111 \\
38 & 0.80 & 0.20 & 0.28 & 222 \\
59.5 & 0.71 & 0.29 & 0.23 & 322 \\
\hline
\end{tabular}

1 Reaction conditions: 100 psi CO, 1000 psi N 2, 100 psi O2, 3 ml D2O/ DCl (pH =1), 15 mg Pd/ carbon (0.9 $\mu$ mol surface Pd atoms), $96 \mathrm{mg} \mathrm{CH} 3 \mathrm{P}(\mathrm{O})(\mathrm{OH})_{2}(1.00 \mathrm{mmol}), 90^{\circ} \mathrm{C} .{ }^{2}$ Turnover number defined as $\left[\mathrm{H}_{3} \mathrm{PO}_{4}\right] /[$ surface Pd atoms] 
Table 9. Oxidation of ethylphosphonic acid. ${ }^{1}$

\begin{tabular}{|c|c|c|c|c|c|c|}
\hline $\begin{array}{l}\text { Time } \\
\text { (h) }\end{array}$ & $\begin{array}{l}\left(\mathrm{C}_{2} \mathrm{H}_{5}\right) \mathrm{P}(\mathrm{O})(\mathrm{OH})_{2} \\
(\mathrm{mmol})\end{array}$ & $\begin{array}{l}\mathrm{HO}_{2} \mathrm{CCH}_{2} \mathrm{P}(\mathrm{O})(\mathrm{OH})_{2} \\
(\mathrm{mmol})\end{array}$ & $\begin{array}{l}\mathrm{H}_{3} \mathrm{PO}_{4} \\
\text { (mmol) }\end{array}$ & $\begin{array}{l}\mathrm{CH}_{3} \mathrm{CO}_{2} \mathrm{H} \\
(\mathrm{mmol})\end{array}$ & $\begin{array}{l}\mathrm{HCO}_{2} \mathrm{H} \\
(\mathrm{mmol})\end{array}$ & $\operatorname{TON}^{2}$ \\
\hline 0 & 1.00 & 0.00 & 0.00 & 0.00 & 0.00 & 0 \\
\hline 18 & 0.71 & 0.10 & 0.19 & 0.05 & 0.24 & 322 \\
\hline 38 & 0.43 & 0.20 & 0.36 & 0.09 & 0.46 & 622 \\
\hline 59.5 & 0.14 & 0.30 & 0.56 & 0.13 & 0.45 & 956 \\
\hline
\end{tabular}

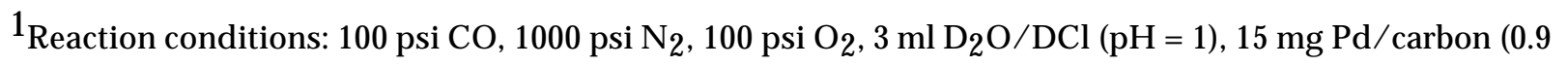

$\mu \mathrm{mol}$ surface $\mathrm{Pd}$ atoms), $110 \mathrm{mg}\left(\mathrm{C}_{2} \mathrm{H}_{5}\right) \mathrm{P}(\mathrm{O})(\mathrm{OH})_{2}(1.00 \mathrm{mmol}), 90^{\circ} \mathrm{C}$. ${ }^{2}$ Turnover number defined as \{ $\left.\mathrm{HO}_{2} \mathrm{CCH}_{2} \mathrm{P}(\mathrm{O})(\mathrm{OH})_{2}\right]+\left[\mathrm{H}_{3} \mathrm{PO}_{4}\right] y$ [surface Pd atoms] 
Table 10. Oxidation of methyl-sulfur compounds. ${ }^{1}$

\begin{tabular}{|c|c|c|c|c|c|}
\hline $\begin{array}{l}\text { Substrate } \\
\text { (mmol) }\end{array}$ & $\begin{array}{l}\text { Time } \\
\text { (h) }\end{array}$ & $\begin{array}{l}\left(\mathrm{CH}_{3}\right)_{2} \mathrm{~S} \\
(\mathrm{mmol})\end{array}$ & $\begin{array}{l}\left(\mathrm{CH}_{3}\right)_{2} \mathrm{SO} \\
(\mathrm{mmol})\end{array}$ & $\begin{array}{l}\left(\mathrm{CH}_{3}\right)_{2} \mathrm{SO}_{2} \\
(\mathrm{mmol})\end{array}$ & $\begin{array}{l}\mathrm{CH}_{3} \mathrm{SO}_{3} \mathrm{H} \\
(\mathrm{mmol})\end{array}$ \\
\hline $\begin{array}{l}\left(\mathrm{CH}_{3}\right)_{2} \mathrm{~S}^{2,3} \\
(1.00)\end{array}$ & 17.0 & 0.39 & 0.22 & ---- & 0.04 \\
\hline $\begin{array}{l}\left(\mathrm{CH}_{3}\right)_{2} \mathrm{SO}^{2} \\
(0.50)\end{array}$ & 18.5 & ---- & ---- & 0.14 & 0.30 \\
\hline $\begin{array}{l}\left(\mathrm{CH}_{3}\right)_{2} \mathrm{SO}_{2} \\
(0.50)\end{array}$ & 18.5 & --- & ---- & 0.47 & 0.03 \\
\hline
\end{tabular}

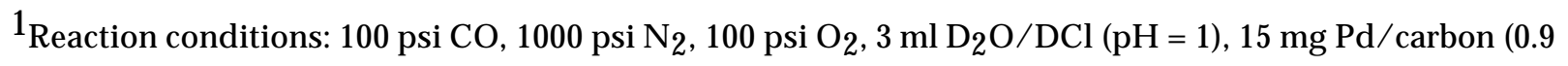

$\mu \mathrm{mol}$ surface $\mathrm{Pd}$ atoms), $100^{\circ} \mathrm{C}$. ${ }^{2}$ Deep oxidation to $\mathrm{HCO}_{2} \mathrm{H}$ and $\mathrm{CO}_{2}$ occurred. ${ }^{3}$ Solvent: $1.5 \mathrm{ml}$ $\mathrm{CF}_{3} \mathrm{CF}_{2} \mathrm{CF}_{2} \mathrm{CO}_{2} \mathrm{H}+1.5 \mathrm{ml} \mathrm{D} 2 \mathrm{O} / \mathrm{DCl}(\mathrm{pH}=1)$. 


\section{RELEVANCE, IMPACT AND TECHNOLOGY TRANSFER}

A most pressing need for the DOE environmental management program is the removal of toxic organics present in groundwater and soil at specific DOE sites. While several remediation procedures have been proposed, they suffer from one or more drawbacks. The objective of the present research was to develop new catalytic procedures for the removal of toxic organics from the environment through their deep oxidation to harmless products. It is clear from the results obtained that we have discovered an exceptional ly versatile catalytic system for the deep oxidation of toxic organics in water. This system possesses several attractive features not found simultaneously in other reported systems. These are (a) the ability to directly utilize dioxygen as the oxidant, (b) the ability to carry out the deep oxidation of a particularly wide range of functional organics, and (c) the ease of recovery of the catalyst by simple filtration.

While the work performed under the present grant has led to the discovery of a new, versatile, remediation procedure for the removal of toxic organics from the environment, further work is required prior to field testing. This includes (a) the optimization of the various process parameters, (b) the quantitative analysis of the process efficiency under optimal conditions, and (c) obtaining a better understanding of how the catalytic process works. Accordingly, we will be submitting a renewal proposal outlining these future research plans. 


\section{PROJECT PRODUCTIVITY}

The proposed goal of the project was fundamental research leading to the discovery a new

procedure for the removal toxic organics from the environment through their deep oxidation to harmless products. This goal was achieved.

\section{PERSONNEL SUPPORTED}

Graduate students: Terrence H ogan and AnnePifer

Postdoctorate: Dr. Chengyu Shen 


\section{PUBLICATIONS IN PEER-REVIEWED JOURN ALS}

1. "A Broad Spectrum Catalytic System for Removal of Toxic Organics from Water by Deep Oxidation Using Dioxygen as the Oxidant,"

Terrence Hogan, Robert Simpson, Minren Lin, and A yusman Sen,

Catal. Lett., 1996, 40, 95.

2. “The Deep Oxidation of Chemical Warfare A gent Models: FacileCatalytic Oxidative Cleavage of Phosphorus-Carbon and Sulfur-Carbon Bonds using Dioxygen,"

Terrence Hogan, Robert Simpson, Minren Lin, and Ayusman Sen,

Catal. Lett., 1997, 49, 59.

3. “A Broad Spectrum Catalytic System for the Deep Oxidation of Toxic Organics in A queous Medium Using Dioxygen as the Oxidant,"

Anne Pifer, Terrence Hogan, Benjamin Snedeker, Robert Simpson, M inren Lin, Chengyu Shen, and Ayusman Sen,

J. A m. Chem. Soc., 1999, 121, 7485.

4. "Chemical Recycling of Plastics to Useful Organics by Oxidative Degradation," Anne Pifer and Ayusman Sen, Angew. Chem., Int. Ed., 1998, 37, 3306.

\section{INTERACTIONS}

Our work was presented at a DOE-EMSP Workshop and at several N ational M eetings of the American Chemical Society. 


\section{LITERATURE CITED}

1. Reviews: (a) D rinking W ater and H ealth; National Academy of Sciences: Washington, DC, 1977; Ch. VI.

(b) O rganic Contaminants in W aster W ater, Sludge and Sediment; Quaghebeur, D.; Temmerman, I.; Angeletti, G., Eds.; Elsevier: New York, 1989. (c) O rganic Contaminants in the Environment; Jones, K. C., Ed.; Elsevier: New York, 1991.

2. Reviews: (a) Gottschalk, G.; Knackmuss, H.J. A ngew. Chem. Int. Ed. 1993, 32 1398. (b) Bioremediation of Chlorinated and Polycyclic A romatic H ydrocarbon Compounds; Hinchee, R. E.; Leeson, A.; Semprini, L.; Ong, S. K., Eds.; Lewis: Boca Raton, FL, 1994. (c) A bramowicz, D. A.; Olson, D. R. Chemtech 1995, 36.

3. Reviews: (a) Pelizzetti, E.; Minero, C.; Vincenti, M. Technologies for Environmental Cleanup: Toxic and H azardous W aste M anagement; A vogadro A.; Ragaini, R. C., Eds.; Euro Courses: Environ. M anage. 1994, 2, 101. (b) Fox M. A.; Dulay, M. T. Chem. Rev. 1993, 93, 341 (c) Minero, C.; Pelizzetti, E.; Pichat, P.; Sega, M.; Vincenti, M. Environ. Sci. Technol. 1995, 29, 2226. (d) Dong C.; Huang, C.-P. A dv. Chem. Ser. 1995, 244, 291. (e) Dillert, R.; Fornefett, I.; Siebers, U.; Bahnemann, D. J. Photochem. Photobiol. A : Chem. 1996, 94, 231.

4. Recent representative examples: (a) Koyama, O.; Kamagata, Y.; Nakamura, K. W at. Res. 1994, $28,895$.

(b) Kiwi, J.; Pulgarin, C.; Peringer, P. A ppl. Catal. B: Environmental 1994, 3, 335. (c) Sorokin A.; Meunier, B. J. Chem. Soc., Chem. Commun. 1994, 1799. (d) Fortuny, A.; Ferrer, C.; Bengoa, C.; Font J.; Fabregat, A. Catal. Today 1995, 24, 79. (e)

Li, Z. M.; Comfort, S. D.; Shea, P. J. J. Environ. Q ual. 1997, 26, 480.

5. (a) Sorokin, A.; Seris, J.-L.; Meunier, B. Science 1995, 268, 1163. (b) Sorokin, A.; Seris, J.-L.; Meunier, B. Chim. Ind. 1995, 151.

6. (a) Lin M.; Sen, A. J. A m. Chem. Soc. 1992, 114, 7307. (b) Lin, M.; Hogan, T. E.; Sen, A. J. A m. Chem. Soc. 1997, 119, 6048.

7. Gosser, L. W. U. S. Patent 4,681,751 (1987).

8. (a) Rossella, B.; D'Aloisio, R.; Bianchi, D. Eur. Pat. A ppl. EP 788,998 (1997). (b) Bianchi, D.; Rossella, B.; D'Aloisio, R.; Ricci, M.; Soattini, S. Eur. Pat. A ppl. EP 808,796 A 1 (1997). 
9. Recent reviews on monooxygenases and their synthetic analogs: (a) M etalloporphyrins in Catalytic Oxidations; Sheldon, R. A., Ed.; Marcel Dekker: N ew York, 1994. (b) M etalloporphyrins Catalyzed O xidations; Montanari, F.; Casella, L., Eds.; Kluwer: Dordrecht, 1994.

10. Hogan, T.; Simpson, R.; Lin, M.; Sen, A. C atal. Lett., 1996, 40, 95.

11. Hogan, T.; Simpson, R.; Lin, M.; Sen, A. Catal. Lett., 1997, 49, 59.

12. Pifer, A.; Hogan, T.; Snedeker, B.; Simpson, R.; Lin, M.; Shen, C.; Sen, A. J. A m. Chem. Soc., 1999, 121, 7485.

13. (a) Higson, F. K. In A dvanced and A pplied M icrobiology; N eidleman, S. L.; Laskin, A. I., Eds.; A cademic: San Diego, 1992; vol. 37, p. 1. (b) Kaake, R. H.; Roberts, D. J.; Stevens, T. O.; Crawford, R. L.; Crawford, D. L. A pp. Environ. M icrobiol. 1992, 58, 1683.

14. Funk, S. B.; Crawford, D. L.; Crawford, R. L.; Mead G.; Davis-Hooper, W. A pp. Biochem. Biotech. 1995, 51,625 .

15. Hutson, A. C.; Sen, A. J. A m. Chem. Soc. 1994, 116, 4527.

16. (a) Specific example: Hosokawa, T.; N akahira, T.; Takano, M.; Murahashi, S. J M ol. Catal. 1992, 74, 489.

(b) Review: Catalytic O xidations with H ydrogen Peroxide as O xidant; Strukul, G., Ed.; Kluwer Academic: Dordrecht, 1992. 